\title{
Julian Kałowski
}

\section{Konstytucje jako zabezpieczenie celu i zadań instytutów życia konsekrowanego}

Prawo Kanoniczne : kwartalnik prawno-historyczny 36/3-4, 5-19

1993

Artykuł został zdigitalizowany i opracowany do udostępnienia w internecie przez Muzeum Historii Polski w ramach prac podejmowanych na rzecz zapewnienia otwartego, powszechnego i trwałego dostępu do polskiego dorobku naukowego i kulturalnego. Artykuł jest umieszczony w kolekcji cyfrowej bazhum.muzhp.pl, gromadzącej zawartość polskich czasopism humanistycznych i społecznych.

Tekst jest udostępniony do wykorzystania w ramach dozwolonego użytku. 


\section{KONSTYTUCJE JAKO ZABEZPIECZENHE CELU I ZADAŃ INSTYTUTOW ŻYCIA KONSEKROWANEGO}

Tréśc: Wstęp - I. Cel i zadania instytutu. 1. Formowanie się celów i zadań. 2. Normy z 1901 r. 3. Sobór Watykański II oraz późniejsze dokumenty. - II. Konstytucje. - Zakończenie.

\section{Wstęp}

Instytuty życia konsekrowanego podlegały i podlegają ciągłym przemianom. W pierwszych wiekach Kościoła istnieli tylko pustelnicy, czyli anachoreci (eremici). Mieszkali pojedynczo w swoich pustelniach, pozostawali bez przełożonych, udawali się, dokąd chcieli, i czynili, co chcieli. Później powstała instytucja mnichów. Wobec niektórych z nich, szczególnie tzw. girowagów (włóczęgów), tj. opuszczających bez pozwolenia biskupa miejsce swego zamieszkania, trzeba było stosować specjalne środki. Biskup, korzystając z pomocy władzy świeckiej, był zmuszony usuwać ich na przykład $\mathrm{z}$ osad ludzkich i doprowadzać do klasztoru ${ }^{1}$.

Bardzo szybko, bo już na przełomie trzeciego i czwartego wieku, św. Pachomiusz (†346) zapoczątkował na Wschodzie zorganizowaną formę życia monastycznego. Na Zachodzie uczynił to św. Benedykt z Nursji (†547). Mając na względzie wierniejsze naśladowanie przez mnichów Chrystusa, św. Pachomiusz, św. Benedykt oraz inni zakonodawcy nakazywali swoim uczniom mieszkanie w klasztorach, prowadzenie życia wspólnego, uzależnienie się od przełożonych i życie według zredagowanych dla nich regul ${ }^{2}$. W późniejszych wiekach powstawały inne formy relizacji rad ewangelicznych, takie jak zakony, zgromadzenia zakonne, stowarzyszenia prowadzące życie na wzór zakonów, instytuty świeckie, eremici, stan dziewic, stan wdów ${ }^{3}$.

1 C. XVI. c. 17-18: ,Quidam monachi nichil habentes sibi iniunctum a proprio episcopo, interdum uero etiam illi. qui ab eo fuerant excommunicati, ueniunt ad ciuitatem Constantinopolitanam, et in ea perturbationes tranquilitati ecclesiasticae inferunt, et diuersorum domos corrumpunt. Statuit igitur hec sancta sinodus, hos primum commoneri, ut exeant de ragia ciuitate; demum eos inuitos deici, ac per defensorem conpelli, ut ad sua loca perueniant.

Probinum Sabariae, et Milianum, atque Probianum, uel alios pseudomonachos Johanni defensori precipimus ut eos debeat detinere, quatinus, si quam desiderant suae contentionis rationem cognoscere, ad nos ut informentur debeant exhiberi. Certe si sola obstinatione ab ecclesiastico corpore sunt scissi, in Reatina (sicut petisti) insula ut exulentur, predicto defensori duximus iniungendum".

2 M. A u gè, Dalle origini a S. Benedetto, w: Storia della vita religiosa, Brescia 1988 , s. 41-52, 103-114; L. Dat rin o, Il primo monachesimo, Roma 1984, s. 19-22, $57-63$

3 Cadex Canonum Ecclesiarum Orientalium, kan. 570-572; kan. 603-604 KPK/1983; J. Cre usen, De iuridica status religiosi evolutione. Synopsis historica, Romae 1963; M. A u gè, E. S. S a n tos, L. Boriello, Storia della vita religiosa. 
Instytuty życia konsekrowanego od początku miały ściśle określone zadania, czyli cele. Jedne $z$ nich oddawały się kontemplacji, inne ewangelizowały oraz prowadziły różnego rodzaju działalność charytatywną. Jest sprawą oczywistą, że instytuty życia konsekrowanego - co świadomie czy nieświadomie bywa niedoceniane - wnosify i wnosza wielki wklad w dzieło ewangelizacji. Pierwsi zakonnicy, a byli to mnisi, osiedlali się na nowych terenach i tam nie tylko ewangelizowali, ale również uczyli ludzi rzemiosła, uprawy ziemi etc.

$\mathrm{Na}$ instytuty życia konsekrowanego i stowarzyszenia życia apostolskiego czekały i czekaja różne dziedziny działạlności. Dlatego każdy z instytutów czy stowarzyszeń - o ile chce być pożyteczny i wypełniać swoją rolę w Kościele i świecie - musi postępować zgodnie ze swoim celem, zachowując charakter, charyzmat i dziedzictwo nakreślone w konstytucjach oraz przekazane przez tradycję.

$Z$ doświadczenia wiadomo, że cel i zadania każdej instytucji - choćby najdoskonalszej - mogą ulegać wypaczeniom. Dlatego musi istnieć sposób zabezpieczania celu i zadań każdego instytutu życia konsekrowanego. Rolę tę spełniają konstytucje zatwierdzone przez kompetentną władzę kościelnąa ${ }^{4}$.

\section{Cele i zadania instytutu}

Powstanie każdego $\mathrm{z}$ instytutów życia konsekrowanego oraz stowarzyszeń życia apostolskiego wynikało z konieczności zaspokojenia jakiejś potrzeby oraz wiązało się $\mathrm{z}$ wypełnianiem $\mathrm{w}$ Kościele $\mathrm{i} w$ świecie ściśle określonych zadań. „Stąd też - czytamy w konstytucji Lumen gentium - wyrosły niby na drzewie, które się cudownie i bujnie rozkrzewiło na roli Pańskiej z danego przez Boga zalążka, rozmaite formy życia samotnego lub wspólnego, rozmaite rodziny zakonne, które pomnażają to, co służy zarówno pożytkowi ich członków, jak i dobru całego ciała Chrystusowego. Rodziny te bowiem dają członkom swym pomoc polegającą na umocnieniu ich w danym sposobie życia na wypróbowanej nauce prowadzącej do osiągnięcia doskonałości, na wspólnocie braterskiej w shużbie Chrystusowej i na umocnionej przez poshuszeństwo wolności, tak iż moga oni bezpiecznie wypelniać swe śluby zakonne i zachowywać je wiernie oraz czynić radośnie postępy na drodze miłości"'. Wydaje się zatem rzeczą bardzo wskazaną przypomnieć, a także omówić prawne kwestie dotyczące celów, czyli zadań instytutów życia konsekrowanego.

${ }^{4}$ L. R. Ravasi, De regulis et constitutionibus religiosorum, Romae 1958; G. R occa, Regola e costituzioni nel diritto canonico, Dizionario degli istituti di perfezione, vol. VII, Roma 1983, kol. 1440-1449; J. S und a r a R a j, The juridical nature of the religious constitutions in the law of the Church, Commentarium pro religiosis et missionariis, 72 (1991), $211-260 ; \mathrm{Ph}$. M a r o to, Regulae et particulares constitutiones religionum ex Iure Decretalim usque ad Codicem. Commentarium pro religiosis et missionariis 17 (1936), 354-361; 18 (1937), 26-36, 164-174, $244-269$.

Sobór Watykański II, Konstytucja dogmatyczna o Kościele Lumen gentium, n. 44. 
Cel (finis) albo zadanie (scopus) jest to zamysł przyświecający osobom, które powołują $\mathrm{w}$ określonym czasie do istnienia instytut życia konsekrowanego ${ }^{6}$. Cel lub zadanie instytutu życia konsekrowanego jest to innymi słowy to, do czego on zmierza, co chce osiągnąc poprzez swoich członków, struktury oraz sposób życia i realizację rad ewangelicznych ${ }^{7}$.

Należy zaznaczyć, że ponieważ każdy instytut życia konsekrowanego jest w Kościele osobą prawną, dlatego też musi mieć określony cel i zadania, w przeciwnym wypadku nie ma racji bytu ${ }^{8}$. Kodeks Prawa Kanonicznego z 1983 r. stwierdza, że kompetentna władza Kościoła powinna nadawać osobowość prawną tylko tym zespołom osób lub rzeczy, które realizują cel rzeczywiście pożyteczny oraz posiadają środki do jego realizacji ${ }^{9}$.

Według Konstytucji Dogmatycznej o Kościele Lumen gentium celem wszystkich instytutów życia konsekrowanego jest praktykowanie rad ewangelicznych, oddanie się na własność Bogu i poświęcenie się shużbie Bożej i Jego czci. W dokumencie czytamy: „Przez śluby albo inne święte więzy naturą swą podobne do ślubów, którymi chrześcijanin zobowiązuje się do praktykowania trzech rad ewangelicznych, oddaje się całkowicie na własność umilowanemu nade wszystko Bogu, tak że z nowego i szczególnego tytułu poświęca się służbie Bożej i Jego czci. Już wprawdzie przez chrzest umarł dla grzechu i poświęcony został Bogu, aby jednak móc otrzymać obfitsze owoce laski chrztu, postanawia przez ślubowanie rad ewangelicznych w Kościele uwolnić się od przeszkód, które mogłyby go odwieść od żarliwej miłości i od doskonałości kultu Bożego, i jeszcze ściślej poświęca się służbie Bożej"10.

6 A. Carminati, Fini della religione, Dizionario degli istituti di perfezione, vol. IV, Roma 1977, kol. 40; I fini dello stato religioso e il servizio della Chiesa, Torino 1974, s. 10 n.; R. Bernini, Consacrati a Dio Solo. Catechismo della vita religiosa, Roma 1987, s. 269.

7 R. Bernini, s. 269.

$8 \mathrm{G}$. Michiels, Principia generalia de personis in Ecclesia, Romae 19552, s. 383: „Finem determinatum esse essentiale personae moralis elementum, non est cur fuse probemus; quoad personam moralem non collegialem apprime patet scopum a fundatore intentum esse centrale eius nucleum, quippe cum ad hoc solum creetur institutum ut actuetur iste scopus; in persona morali collegiali vero scopus intentus est praecipuus ad cooperationem humanam stimulus, cohaesionis vinculum et attractionis centrum, ita ut ex hoc elemento teleologico revera derivetur personae moralis character unitarius, propria vi competat individualitas ac determinetur propria eius activitas"; M. Conte a Coronat a, Institutiones iuris canonici, vol. I. Marietti 1950, s. 161: „Alterum elementum quod ad intrinsecam personae iuridicae naturam pertinet finis est; 'qui necessario semper habetur et pro personae ecclesiasticae natura, religiosus aut caritativus esse debet... Si finis personae moralis deficiat ipsa persona deficere dicenda est, quia elementum essentiale deest..."

9 Kan. $114 \$ 3 \mathrm{KPK} / 1983$ : „Kompetentna wladza Kościoła nie powinna nadawać osobowości prawnej, jak tylko tym zespołom osób lub rzeczy, które realizują cel rzeczywiście pożyteczny oraz - po rozważeniu wszystkiego - posiadają środki, które według przewidywań wystarczają do osiągnięcia ustalonego celu".

${ }_{10}^{\circ}$ LG, n. 44; A. Ca rm in a ti, I fini delle religioni, kol. 40. 


\section{Formowanie się celów $i$ zadań}

W starożytnych regułach zakonnych oraz innych aktach prawnych różnych zakonodawców i reformatorów nie było wyraźnych wytycznych dotyezących celów, czyli szczegółowych zadań właściwych dla danego instytutu życia konsekrowanego ${ }^{11}$. Działo się tak, ponieważ dawne reguły zakonne oraz inne akty prawne redagowano $\mathrm{w}$ formie ogólnej i zawierały one tylko - poza nielicznymi wyjątkami - krótkie wskazania natury ascetycznej ${ }^{12}$.

Zdaniem niektórych autorów ${ }^{13}$ dopiero Formuły Towarzystwa Jezusowego jako pierwsze mówią o celu instytutu, na który składają się dwa zadania (scopi), tj. własne uświęcenie i apostolstwo ${ }^{14}$. A. Carminati

${ }_{11}$ A. Carminati, I fini delle religioni, kol. 45.

12 A. Carminati, I fini delle religioni, kol. $45 ; \mathrm{Ph}$. Maroto, Regulae et particulares constitutiones sungularum religionum ex lure Decretalium usqua ad Codicem, Commentarium pro religiosis et missionariis 17 (1936) 361: .. Regula dici potest, ad rem nostram, brevior, adstrictior et generatim vetustior collectio complectens primarias aut fundamentales seu principales et communes ordinationes vel normas, quibus fertur ordo seu forma vivendi in Religione. itemque pauca quaedam et praecipua documenta tradita ad moderandam perfectionis religiosae semitam. Constitutiones appellantur amplior, latior et generatim recentior collectio normarum et ordinationum vitae religiosae, quibus distinctius, plenius, magis determinate et particulariter feruntur praescripta etiam minutiora et diffusiora ad religiosam observantiam et vitam perfectam spectantia, atque definiuntur finis, institutum, regimen, munera, obligationes, iura et cetera, alicuius peculiaris Religionis propria";

L. $\mathbf{R}$. $\mathbf{R}$ a va si, De regulis et constitutionibus religiosirum, $\mathrm{s} .9-11$.

${ }_{13}$ A. C a rm in a ti, I fini dello stato religioso e il servizio della Chiesa, s. 32-33.

14 Formuly Instytutu Towarzystwa Jezusowego uznane $\mathrm{i}$ zatwierdzone przez papieży, P a weł IlI bul. Regimini militantis Ecclesiae 27 września 1540, w: I. Loyola, Konstytucje Towarzystwa Jezusowego, Kraków 1982, s. 7, n. 1: „Ktokolwiek w naszym Towarzystwie, które pragniemy naznaczyć imieniem Jezusa, zechce walczyć pod sztandarem Krzyża dla Boga i służyć samemu Panu oraz Jego Zastępcy na ziemi. biskupowi rzymskiemu, ten winien po zlożeniu uroczystego ślubu dozgonnej czystości dobrze sobie uświadomić, że jest członkiem Towarzystwa, którego glównym celem jest przyczyniać się do postępu dusz w życiu i nauce chrześcijańskiej, do szerzenia wiary przez publiczne kazania, posługę słowa Bożego, Ćwiczenia duchowne i dzieła milości, a w szczególności przez nauczanie religii chrześcijańskiej dzieci i ludzi niewyksztalconych oraz przez niesienie pociechy duchownej w słuchaniu spowiedzi wiernych. Ma się też troszczyć o to, żeby na pierwszym miejscu mieć zawsze przed oczyma Boga, a następnie sposób życia swego Instytutu, który jest pewnego rodzaju drogą do Niego, oraz żeby osiągnąc c wszelkimi siłami ten cel ukazany mu przez Boga. Jednakże każdy ma osiągać ten cel w miarę udzielonej mu laski przez Ducha Swiętego i wedlug wlasnego stopnia powolania (a to dlatego, żeby nie kierować się przypadkiem gorliwością bez-rozeznania") J u li u sz III, bul. Exposcit debitum, 21 lipca 1550 , s. 12, n. 1: „Ktokolwiek chce walczyć pod sztandarem Krzyża dia Boga i służyć samemu Panu i. Kościołowi, Jego Oblubienicy, w naszym Towarzystwie, które pragniemy naznaczyć imieniem Jezusa, pod wodzą Zastępcy Chrystusa na ziemi, rzymskiego biskupa, ten po złożeniu uroczystego ślubu dozgonnej czystości, ubóstwa i posłuszeństwa winien sobie dobrze uświadomić, że jest członkiem Towarzystwa ustanowionego glównie w tym celu, żeby zmierzało do obrony i szerzenia wiary oraz doskonalenia dusz $w$ życiu i nauce chrześcijańskiej. Cel ten osiąga przez publiczne głoszenie kazań, wykłady i wszelkiego rodzaju posługe slowa Bożego oraz przez Cwiczenia duchowne, nauczanie religii dzieci i ludzi niewykształconych, przez niesicnie pociechy duchowej w shuchaniu spowiedzi wiernych i udzielanie innych sakramentów...". 
zwraca uwagę na to, że cele, czyli zadania sformułowane przez dokumenty Towarzystwa Jezusowego, stały się wzorem dla innych instytutów życia konsekrowanego ${ }^{15}$.

Cel ogólny, wspólny dla wszystkich instytutów życia konsekrowanego, określono takimi terminami, jak pierwszorzędny, pierwszy, główny, wewnętrzny, istotny, zasadniczy. Cel natomiast specjalny, czyli charakterystyczny tylko dla danego instytutu, nazywano drugorzędnym, drugim, specjalnym, szczegółowym oraz zewnętrznym ${ }^{16}$.

\section{Normy z $1901 \mathrm{r}$.}

Dokument Kongregacji Biskupów i Zakonników promulgowany 28 czerwca 1901 r. pt. Normy, wedlug których zwykla postępować Kongregacja Biskupów $i$ Zakonników przy zatwierdzaniu instytutów o ślubach prostych ${ }^{17}$ polecał, by wszystkie konstytucje zakonne w sposób wyraźny, jednoznaczny $\mathrm{i}$ w osobnych numerach zawierały wskazania odnoszące się zarówno do celu ogólnego, jak i szczegółowego ${ }^{18}$.

Należy zaznaczyć, że już wcześniej Kongregacja Biskupów i Zakonników stosowała praktykę, w sposób oficjalny wyrażoną dopiero w Normach ${ }^{19}$, polegająca na wymaganiu, aby w konstytucjach były dokładnie określone cel główny i specjalny ${ }^{20}$.

Normy postanawiały, że pierwszym i ogólnym celem każdego stowarzyszenia - wspólnym dla wszystkich zgromadzeń o ślubach prostych - jest uświęcenie członków przez zachowanie trzech ślubów oraz Konstytucji, czyli kodeksu fundamentalnego ${ }^{21}$. W kwestii celu drugorzędnego, właściwego dla każdego instytutu, Normy zarządzały, że są nim ,dzieła miłości względem Boga i bliźniego, dla których wykonywania Zgromadzenie, czyli instytut, zostało ustanowione"22.

Wytyczne zawarte w omawianym dokumencie polecały także, by w Konstytucjach dokładnie rozróżnić oba cele, tj. pierwszorzędny (główny) i drugorzędny (szczególowy), zdefiniować je w jasnych, bez popadania w prze-

15 A. Carm in ati, I fini delle religioni, kol. 45.

16 A. Ca rm in a $\mathrm{i}$, I fini delle religioni, kol. 45; I fini dello stato religioso e il servizio della Chiesa, s. 148-149.

17 Normae secundum quas S. Congr. Episcoporum et Regularium procedere solet in approbandis novis institutis votorum simplicium, 28 iunii 1901, w: T. Schaefer, De religiosis ad normam Codicis Iuris Canonici, Roma 1947, s. $1102-1135$.

18 Tamże, n. 8-17.

19 Collectanea in usum Secretariae Sacrae Congregationis Episcoporum et Regularium cura A. B izza r ri, Romae 1885 , s. 772-807.

${ }_{20}$ Tamże.

21 Normae, n. 42: „Finis primarius et generalis Instituti cuiuslibet, qui communis et omnibus Congregationibus votorum simplicium, est sanctificatio membrorum suorum per observantiam trium eorumdem votorum et propriarum Constitutionum".

${ }_{22}$ Tamże, n. 43: „Finis secundarius et specialis, unicuique scilicet Instituto proprius, constituitur in illis peculiaribus caritatis operibus erga Deum aut erga proximum, ad quae exercenda Institutum ipsum formatum est". 
sadę i bez stosowania wyszukanych wyrażen, słowach ${ }^{23}$. Cel drugorzędny miał być sformułowany precyzyjnie, nie mógł obejmować zbyt wielu dzieł o różnym charakterze ani też takich, których - chociaż same w sobie są godne polecenia - wykonywanie nie przystoi dziewicom Bogu poświęconym ${ }^{24}$.

Jeśli Stolica Apostolska - jak to zwykło się w prawie mówić - w jakiś sposób ,przyłożyła rękę" (co następowało z chwilą udzielenia pozwolenia na erekcję instytutu, wydania dekretu pochwalnego decretum laudis lub dekretu zatwierdzającego decretum approbationis), nie wolno bylo bez wcześniejszego uzyskania zgody Kongregacji Biskupów i Zakonników ani zmieniać celu drugorzędnego, ani też dodawać do niego na sposób stały innych dzieł, które byłyby mu przeciwne ${ }^{25}$. Powyższa dyrektywa Stolicy Apostolskiej obowiązuje do chwili obecnej.

W trosce o dobro duchowe zakonników, a szczególnie zakonnic, Stolica Apostolska nie wyrażała zgody (lub czynila to niezmiernie rzadko i pod różnymi warunkami) na to, by wyłącznym celem żeńskiego instytutu zakonnego były:

1. Pielęgnowanie chorych - w tym zarówno mężczyzn, jak i niewiast - w domach prywatnych albo świadczenie stalych posług w domach rodzin ubogich lub robotniczych. Gdyby w uzasadnionych przypadkach zachodziła jednak koniéczność zaaprobowania takiego instytutu, wówczas w jego konstytucjach należało dokładnie określić warunki i przewidzieć środki chroniące siostry przed takimi niebezpieczeństwami, jak na przykład związanie się z samotnym mężczyzną, któremu by usługiwaty ${ }^{26}$.

2. Prowadzenie sanatoriów, szpitali lub domów, w których odbywalyby się różnego rodzaju imprezy rozrywkowe dla osób obojga płci, urządzanie przytułków dla kapłanów, spełnianie posług w seminariach lub też w innych domach przeznaczonych dla duchownych, nauczanie w szkołach męskich lub koedukcyjnych ${ }^{27}$.

${ }^{23}$ Tamże, n. 44: „Isti duo fines accurate distinquantur, et exprimantur clare, temperatis verbis, sine exaggeratione".

${ }_{24}$ Tamże, n. 45: „Finis secundarius sit apprime definitus et circumscriptus; ne complectatur opera numero plurima et indole discrepantia; nec talia quae, quamvis in se laude digna, virgines tamen Deo dicatas minime decent".

${ }_{25}$ Tamże, n. 46: „Postquam Sedes Apostolica alicui Instituto manus apposuit, huic integrum non est, finem suum secundarium mutare in alium, nec superaddere alia opera diversi generis ad modum permanentis et generalis novi scopi Instituti sine venia Sacrae Congregationis".

26 Tamże, n. 13: „Haud facile approbanda sunt nova sororum Instituta, quae sibi proponunt finem in privatorum domiciliis infirmos utriusque sexus diurna atque nocturna cura iuvandi, vel domesticum servitium quotidianum in familiis pauperum et operariorum exercendi. Si vero approbatio aliquando et ob iustas causas concedenda videatur, in Constitutionibus prudenter praescribantur conditiones et cautelae, quibus sorores a periculis liberentur”; S. C. Rel. „Normae secundum quas Sacra Congregatio de Religiosis in novis religiosis congregationibus approbandis procedere solet, 6 mart. 1921, Leges Ecclesiae, II, n. 340, 15.

${ }^{27}$ Normae [1901], n. 14: „Non conceditur approbatio sororum sodalitatiis, quae sibi constituant scopum specialem, instituendi in suis domibus valetudinaria aut 
3. Bezpośrednia opieka nad niemowlętami lub niewiastami rodzącymi w izbach porodowych albo spełnianie innych dzieł charytatywnych, które nie przystoją osobom poświęconym Bogu i noszącym strój zakonny ${ }^{28}$.

4. Oddawanie się licznym pracom zewnętrznym mało różniącym się od siebie, a nawet będącym ze sobą w sprzeczności. Takim instytutom - zgodnie z zaleceniami Kongregacji Biskupów i Zakonników - należało poradzić, by najpierw zdecydowały się na prowadzenie ściśle określonej dzialalności apostolskiej lub charytatywnej, a dopiero później zwrócily się z prośbą o dekret pochwalny (decretum laudis) lub dekret zatwierdzający (decretum approbationis) ${ }^{29}$.

Trzeba zwrócić uwagę na to, że również późniejsze zarządzenia Stolicy Apostolskiej, zawarte w wydanym przez Kongregację Zakonów 6 marca 1921 r. dokumencie pt. Normy, wedlug których zwykla postepować Kongregacja Zakonów przy zatwierdzaniu nowych zgromadzeń zakonnych ${ }^{\mathbf{3 0}}$, w omawianej tutaj kwestii w całości przejęły wytyczne zamieszczone w Normach z 1901 r. $^{31}$

\section{Sobór Watykański II oraz późniejsze dokumenty}

Specjalne zadania, czyli cel drugorzędny, są tak ważne $\mathrm{i}$ istotne dla każdego rodzaju instytutu życia konsekrowanego, że Kościół zawsze zwracał na nie baczną uwagę. Zagadnienia tego nie mógł również pominąć Sobór Watykański II ani inne dokumenty promulgowane przez Stolicę

diversoria pro personis utriusque sexus, - vel hospitia pro sacerdotibus suscipiendis; - sive scopum assumendi gestionem in seminariis clericorum vel in aliis quibuscumque ecclesiasticorum virorum domibus, vel in collegiis alumnorum masculini sexus; - sive scopum docendi in scholis adolescentulorum, aut in iis quae mixtae dicuntur, in quibus scilicet pueri et puellae simul congregantur"; S. C. Rel. Normae..., 6 mart. 1921, n. 16.

${ }_{28}$ Normae [1901], n. 15: „Multo minus probanda sunt Instituta sororum, quae sibi assumendam proponerent curam directam puerulorum in cunis vagientium; vel mulierum parturientium in domibus, vulgo dictis, Maternitatis; - vel alia denique caritatis opera quae virgines Deo dicatas, et habitu ecclesiastico indutas dedecere videntur"; S. C. Rel. Normae... 6 mart. 1921, n. 17.

${ }_{29}$ Normae [1901], n. 8; ,Caute laudanda et approbanda sunt Instituta, quae externos actus multiplices, dissimiles, imo inter se valde dissonos sibi proponunt; ita ut actionem suam ad omnia omnino opera caritatis erga proximum extendere videantur. His suadendum, ut certum ac circumscriptum actionis genus sibi eligant; quo definito, decretum laudis vel approbationis concedi poterit. Nec obstat quod alicubi, puta in terris Missionum, assumere debeant aliquando opera, quae praetergrediuntur finem sibi praestitutum. Aliud enim est Institutum approbare ad universitatem operum generaliter pro omni loco et tempore; et aliud est permittere ut alique eiusdem domus, inspectis locorum adiunctis, ex iusta causa, suadentibus episcopis, et adhibitis cautelis necessariis et opportunis, quaedam operum genera praeter ordinaria munera et officia Instituti alicubi suscipiant"; S. C. Rel., Normae..., 6 mart. 1921, n. 13.

${ }_{30}$ Por. przypis 26.

31 S. C. Rel., Normae.., 6 mart. 1921, n. 13-17. 
Apostolską, a odnoszące się do instytutów zakonnych, świeckich oraz stowarzyszeń życia apostolskiego ${ }^{32}$.

Nauczanie Stolicy Apostolskiej dotyczące instytutów życia zakonnego kładzie nacisk na cel specjalny, czyli zadanie, dla realizacji którego każdy instytut został założony i erygowany oraz otrzymal mandat od najwyższej władzy kościelnej ${ }^{33}$. I tak w Dekrecie o przystosowanej odnowie życia zakonnego Perfectae caritatis czytamy: „Bardzo liczne są w Kościele instytuty, czy to kleryckie czy laickie, oddane różnym dziełom apostolskim; mają one według udzielonej sobie łaski różne dary: bądź urząd posługiwania dla posług duchowych, bądź urząd nauczania dla wypełniania czynności nauczycielskich, bądź dar upominania dla karcenia; kto zajmuje się rozdawaniem, niech to czyni z prostota, kto pełni uczynki miłosierdzia, niech to czyni ochoczo (por. Rz 12, 5-8...)"34.

Najwyższa władza Kościoła katolickiego zaleca zarówno instytutom życia konsekrowanego Kościoła łacińskiego, czyli zachodniego, jak i Kościołów Wschodnich, dostosowanie się do wymagań czasów, miejsca i okoliczności ${ }^{35}$. Wytyczne Soboru Watykańskiego II wprawdzie również polecały instytutom zakonnym dokonanie przystosowanej odnowy życia, nie pozwalały jednak ani na zmianę charakteru i celu instytutu, ani też na oddalenie się od ducha i zamiarów Założycieli. „,Jest rzeczą korzystną dla samego Kościoła - czytamy w dokumencie soborowym - żeby instytuty miały odrębny charakter i własne zadania. Należy więc wiernie rozeznawać i zachowywać ducha i wlaściwe zamiary założycieli, jak również zdrowe tradycje, bo wszystko to stanowi dziedziczną własność każdego instytutu"36. Przepisy wykonawcze do soborowego Dekretu o przystosowanej odnowie

32 Sobór Watykański II, Dekret o przystosowanej odnowie życia zakonnego Perfectae caritatis; P a w el VI, Motu proprio Ecclesiae Sanctae, przepisy wykonawcze do dekretu Perfectae caritatis, 6 sierpnia 1966, P a wel VI, Charyzmat życia zakonnego. Przemówienia i dokumenty. Wybór i opracowanie A. $\dot{Z} u c h$ owski, T. Sulow ska, Poznań - Warszawa 1974, s. 217, n. 6; Pawel VI, Evangelica testificatio, adhortacja apostolska na temat odnowy życia zakonnego według nauki Soboru Watykańskiego II, Paweł VI, Charyzmat życia zakonnego, s. 237, n. 11; Kan. 578 PKP/1983; kan. 631 \&; Kongregacja Zakonów i Instytutów Swieckich, Istotne elementy nauczania Kościola na temat życia konsekrowanego w zastosowaniu do instytutów oddajqcych się pracy apostolskiej, 31 maja 1983, J a n P a weł II, O życiu zakonnym. Przemówienia. Listy apostolskie. Instrukcje. Wybór tekstów i opracowanie E. Wer on, A. Ja roch, Poznań - Warszawa 1984, s. 449-450, §13-17.

33 Tamże.

34 Dekret o przystosowanej odnowie życia zakonnego Perfectae caritatis, n. 8; Paweł VI, Evangelica testificatio, n. 11; kan. 578 KPK/1983.

${ }^{35} \mathrm{P}$ i u $\mathrm{S}$ XII, Allocutio Delegatis conventui generali universis religiosis Ordinibus, Congregationibus ac Societatibus Institutisque saecularibus, Romae habita, 8 dec. 1950 . Leges Ecclesiae, II, n. 2173: „Plerumque enim contigit, ut legiferi patres religiosorum Institutorum novum suum excogitarent opus, quo emergentibus neque moram patientibus Ecclesiae necessitatibus vel muneribus occurrent; itaque cum suo tempore sua exaequabant incepta. Quodsi vultis patriis insistere exemplis, eo modo quo ipsi se gesserunt, ita et vos agite. Aequalium vestrorum, inter quos vivitis, scrutamini opiniones, iudicia, mores et, si ibi particulae boni et iusti inveniantur, pretiosis hisce elementis potimini; altier eos collustrare, iuvare, sublevare, ducere non valetis".

${ }^{36}$ Dekret o przystosowanej odnowie życia zakonnego Perfectae caritatis, n. 2 b. 
życia zakonnego Perfectae curitatis upoważniły wprawdzie kapitułe generalną specjalną do wprowadzania zmian do konstytucji, ale z zastrzeżeniem, „byleby pozostały zachowane: cel, natura i właściwy charakter Instytutu" ${ }^{37}$.

Dokumenty Stolicy Apostolskiej ustawicznie zwracają uwagę na to, że cel, charakter i charyzmat stanowią niezastąpione bogactwo Kościoła, a ich zachowywanie jest potwierdzeniem potrzeby istnienia instytutu, jego żywotności i rozwoju ${ }^{\mathbf{3 8}}$.

\section{Konstytucje}

Cel, zadania, charakter, naturę i specyficzne cechy nadane poszczególnym instytutom przez ich założycieli oraz sławnych członków, często wyniesionych na ołtarze, ulegają nieustannej presji zmieniających się warunków, w których działa instytut. W konsekwencji pojawiają się tendencje zmierzajace do modyfikowania, a nawet całkowitego rezygnowania $\mathrm{z}$ pierwotnego oblicza instytutu. Dlatego - co wynika $z$ doświadczeń Kościoła, potwierdzonych wydaniem licznych aktów prawnych - cel, zadania i charakter instytutu muszą być chronione przez kompetentną wladzę Kościoła ${ }^{39}$.

Należy mocno podkreślić, że żaden instytut życia konsekrowanego ani stowarzyszenie życia apostolskiego nie jest prywatną instytucją przełożonych jednostkowych lub też kapituł, choćby nawet generalnych. Istnieją one, tzn. instytuty, w Kościele i dla Kościoła, a więc całkowicie podlegają jego władzy. Instytut tak długo jest potrzebny i coś znaczy - chociażby nawet liczył niewielu członków - jak długo żyje w nim duch Założyciela. W przeciwnym przypadku dochodzi do skostnienia, zwyrodnienia, a w konsekwencji do zaniku instytutu.

Stolica Apostolska broni wszystkich instytutów życia konsekrowanego - niezależnie od tego, czy są na prawie papieskim, czy też diecezjalnym - przed odejściem od celu i zadań wyznaczonych przez fundatorów, a zatwierdzonych przez Kościól. Stwierdzenie to wynika z przepisu kan. 583 Kodeksu Prawa Kanonicznego z 1983 r., w którym czytamy: „Zmiany podejmowane w instytutach życia konsekrowanego, dotyczące tych elemen-

${ }^{37}$ Motu proprio Ecclesiae Sanctae, przepisy wykonawcze do dekretu Perfectae caritatis, n. 6.

${ }_{38} \mathrm{Pawe}$ a VI, Evangelica testificatio, n. 11; Przemówienie do Kongresu Międzynarodowej Unii Przelożonych Generalnych Żeńskich Instytutów Zakonnych (UISG), 29 września 1970, Charyzmat życia zakonnego, s. 55; Przemówienia do Unii Przelożonych Generalnych (USG), 25 maja 1973, s. 66 ns; Przemówienie do uczestników Kapitul Generalnych Ojcón Karmelitów, Augustianów i Rogacjonistów Serca Jezusowego, 14 września 1968, s. 158-159; Przemówienie do uczestników Kapitul Generalnych czlonków III Zakonu Regularnego świętego Franciszka, Kamilianów, Pallotynów i Orionistów, 6 marca 1969, s. 164.

39 Odnośne dokumenty można znaleźć w takich zbiorach prawnych jak: Collectanea in usum Secretariae Sacrae Congregationis Episcoporum et Regularium; Enchiridion de statiobus perfectionis. Documenta Ecclesiae sodalibus instituendis, Romae 1949; La vita religiosa. Documenti a cura di A. Ravazzi, Milano 1972; Pawel VI, Charyzmat życia zakonnego: Jan Pawel II, O życiu zakonnym. Przemówienie. Listy apostolskie. Instrukcje; Documenti sulla vita religiosa 1963-1985 raccolti di J. A u bry, Torino 1987. 
tów, które uzyskały aprobatę Stolicy Apostolskiej, nie mogą być dokonywane bez jej zgody". Dlatego też - zgodnie z kan. 579 Kodeksu - biskuṕ diecezjalny wydaje pozwolenie na erekcję instytutu życia konsekrowanego po wcześniejszej konsultacji z Kongregacją Instytutów Życia Konsekrowanego i Stowarzyszeń Życia Apostolskiego. Ta ostatnia zaś uzależnia swoją zgodę od tego, czy nowa osoba prawna będzie taka, jak przedstawiona w doręczonych przez biskupa Konstytucjach. Ponadto - zgodnie z Kodeksem Prawa Kanonicznego z 1983 r. - „Kompetentna władza Kościoła nie powinna nadawać osobowości prawnej, jak tylko zespołom osób lub rzeczy, które realizują cel rzeczywiście pożyteczny oraz - po rozważeniu wszystkiego - posiadają środki, które według przewidywań wystarczają do osiągnięcia ustalonego celu"40.

Od początku istnienia instytutów życia konsekrowanego ich cel oraz zadania strzeżone były przez specjalne akty ustawodawcze, tj. reguły, konstytucje lub inaczej zwane zbiory prawne:

Warto w tym miejscu zwrócić uwage na to, że prawo dotyczące różnych form życia zakonnego zarówno dawniej, jak i obecnie (chociaż teraz bardzo rzadko) stosuje zamiennie terminy „regula” i „konstytucje”, mimo że nie są to pojęcia całkowicie równoznaczne ${ }^{41}$. Przed XVI wiekiem słowo „reguła” (regula) było stosowane na określenie krótkiego i zazwyczaj starożytnego zbioru podstawowych i bardzo ogólnych przepisów normujących życie zakonne ${ }^{42}$. Przez „konstytucje” natomiast rozumie się kodeks własny i fundamentalny, który zawiera stałe normy, czyli zasady określające cel, środki służące jego realizacji, sposób praktykowania rad ewangelicznych oraz inne elementy wymagane przez Stolicę Apostol$\mathrm{skaq}^{43}$. Należy również zaznaczyć, że zakony kleryckie powstałe $\mathrm{w}$ XVI i XVIl wieku posiadały konstytucje i reguły, które różniły się między sobą ${ }^{44}$.

Kompetentna władza kościelna - żądając wiernego zachowywania konstytucji, których głównym zadaniem jest ochrona własnego powołania oraz identyczności poszczególnych instytutów - troszczyła się i troszczy o zabezpieczenie celu i zadań poszczególnych instytutów życia konsekrowanego. O prawdziwości tego stwierdzenia można się przekonać $z$ uwag do konstytucji nanoszonych przez Dykasterie Kurii Rzymskiej z racji zatwier-

${ }^{40}$ Kan. $114 \S 3$ KPK/1983; Kan. $100 \$ 1$ KPK/1917; Codex Canonum Ecclesiarum Orientalium, Kan. $921 \S 3$.

${ }_{41}$ L. R. Ravasi, s. 12; J. R. Bar, J. Kalowski, Prawo o instytutach zycia konsekrowanego, Warszawa 1985, s. 42.

42 J. R. B a r, J. Ka łowski, s. 42

43 L. R. R a va si, s. 12: „Constitutiones vero sunt normae religionis primariae et fundamentales a Sede Apostolica confirmatae"; J. Kalowski, Konstytucje $i$ inne zbiory prawne instytutów życia konsekrowanego wedlug Kodeksu Prawa Kanonicznego z 1983 r., Prawo Kanoniczne 29 (1986) nr 1-2, s. 153 i cytowana tam literatura.

${ }_{44}$ L. R. R a va si, s. 12: „Ordines Clericorum Regularium, qui saec. XVI et initio saec. XVII conditi sunt, regulas et constitutiones generatim distincta habent. Regulae apud eos sunt minutiores et particulares praescriptiones, ad mentem constitutionum exaratae et a Capitulis generalibus approbatae". 
dzania tych dokumentów ${ }^{45}$. Dochodziło nawet i do takich przypadków, że najwyższa władza - chcąc zachować tożsamość, cel i zadania poszczególnych instytutów - albo nie zatwierdzała konstytucji, albo też odsyłała je do gruntownego przeredagowania, nakazując powrót do realizacji dziel wytyczonych przez założyciela i uznanych przez Kościól ${ }^{46}$.

Stolica Apostolska w trosce o zabezpieczenie celu i zadań poszczególnych instytutów życia konsekrowanego oraz dla uniknięcia innych niestosowności polecała $w$ sposób bezwzględny usuwać z przesyłanych jej do zatwierdzenia konstytucji różnego rodzaju nieodpowiednie wyrażenia, np. tytuły przysługujące przełożonym ${ }^{47}$. Podobnie postąpiono $\mathrm{w}$ sprawie mianowania spowiednika dla sióstr i otwierania tajemnic sumienia przed przełożonymi ${ }^{48}$.

Czy obecnie - na skutek powszechnego wprowadzenia zasady pomocniczości władzy oraz jej decentralizacji, tj. udzielenia przełożonym większych uprawnień - przełożeni, a zwłaszcza kapituły generalne, mogą zmieniać lub modyfikować cel, zadania i inne istotne cechy instytutu? $\mathrm{Na}$ tak postawione pytanie należy odpowiedzieć negatywnie.

Kościół czuwał i czuwa poprzez konstytucje nad tym, by instytuty życia konsekrowanego zachowywały swoją tożsamość. Niczego nowego w tej materii nie wniósł ani Sobór Watykański II, ani też późniejsze dokumenty wydane przez Stolicę Apostolską. Dokumenty Kościoła promulgowane przez Sobór Watykański II oraz wydane po jego zakończeniu - mimo że zalecały, a nawet nakazywały dostosowanie konstytucji do warunków współczenego świata - przypominały jednak: „Ta Kapituła generalna (chodzi o-kapitułę specjalna) posiada prawo wprowadzania na próbę zmiany pewnych przepisów Konstytucji albo, u Wschodnich Typików, byleby

45 Collectanea in usum Secretariae Sacrae Congregationis Episcoparum et Regularium, s. 772-805 oraz inne nowsze uwagi Kongregacji Instytutów Życia Konsekrowanego i Stowarzyszeń Życia Apostolskiego naniesione przy zatwierdzaniu konstytucji.

46 Tamże.

47 Animadversiones. In constitutiones Sororum Charitatis Filiarum Immaculatae Conceptionis Paderbonensis Dioecesis, expediatae die 10 Martii 1860 N. 6727-5, Collectanea in usum Secretariae Sacrae Congregationis Episcoporum et Regularium, s. 777-778: ...Supprimendus erit Moderatricis generalis titulus Vicariae Christi, et alia huiusmodi, de quibus habebitur ratio, quando Constitutiones examini subiicientur, si satis emandatae non reperiantur".

48 Tamże, s. 776-777: „Ob abusus qui irrepserunt, in praesens Sacra Congregatio minime solet approbare aperitionem conscientiae Superiorissae, sed tantum permittitur, ut Sorores, si velint, pandere possint defectus in regulae observantia et progressum quoad virtutes; de aliis enim ab eis agendum est cum proprio Confessario. Exnorbitans a iure est concedere Superiorissae facultatem nominandi et proponendi Confessarios; cum in huiusmodi deputationibus libertas relinquenda sit Episcopis iuxta Constitutionem Benedicti XIV, incipien. Pastoralis curae, cuius observantia in regulis inserenda erit.

Res periculi plena est relinquere arbitrio Superiorissae generalis eiusque Consilii ius concedendi vocem activam et passivam Sororibius. In aliis institutis vox activa et passiva conceditur Sororibus, quae aliquod annos professionis habuerint, et aliquod munus exercuerint". 
pozostały zachowane: cel, natura i właściwy charakter Instytutu"49. Kiedy natomiast niektóre instytuty życia konsekrowanego chciały się przeorganizować, czyli zmienić swój charakter, Kongregacja Zakonów i Instytutów Ŝwieckich (obecnie zwana Kongregacją Instytutów Życia Konsekrowanego i Stowarzyszeń Życia Apostolskiego) ${ }^{50}$ pomimo nawet długotrwałych dyskusji z reguły nie wyrażała na to zgody, chyba że chodziło o unię lub fuzję.

Należy w tym miejscu przypomnieć, że po Soborze Watykańskim II dążono pod wpływem mody do przeprowadzenia zmian w życiu instytutów. W tym celu organizowano liczne sesje, odbywano podróże, dyskutowano, radzono się różnych ekspertów, w tym nie tylko znawców życia zakonnego, lecz także psychologów, socjologów oraz innych osób mających niewiele wspólnego z życiem zakonnym ${ }^{51}$. Pęd do odchodzenia od źródeł, celów i zadań oraz nieuporządkowana chęć wprowadzenia zmian w sposób natychmiastowy sprawiały, że często źle interpretowano wytyczne Soboru Watykańskiego II nakazujące przeprowadzenie przystosowanej odnowy życia zakonnego. Zapominano, że odnowa powinna uwzględniać obserwancję reguły i konstytucji oraz wierne zachowanie celu i zadań instytutów.

Dostosowując konstytucje do zaleceń Soboru Watykańskiego II, bardzo często - co potwierdzają pracownicy Kongregacji Instytutów Życia Konsekrowanego i Stowarzyszeń Życia Apostolskiego-osoby, które ex officio mialy obowiązek przeprowadzenia odnowy, nie były do tego w rzeczywistości przygotowane. Uczestnicy kapituł specjalnych na przykład czuli się upoważnieni do redagowania całkiem nowych konstytucji, ostro reagując na wszystko, co dawne i oparte na tradycji. Przygotowywane konstytucje często mialy charakter czysto duchowy, a nawet poetycki, eliminowały natomiast $\mathrm{z}$ wielką pieczołowitością konkretne zasady odnoszące się do celu, zadań, życia duchowego, wspólnego, wspólnotowego, formacji, a wreszcie do zarządu ${ }^{52}$.

${ }^{49}$ Motu proprio Ecclesiae Sanctae przepisy wykonawcze do dekretu Perfectae caritatis, n. 6 .

50 Joannes Pa ulus 1I. Constitutio Apostolica de Romana Curia Pastor bonus, 28 iunii 1988, AAS 80 (1988) 886-888.

${ }^{31}$ A. S a u va ge, Agenti del rinnovamento, Informationes SCRIS 1985 n. 2, s. 170: „Per rispondere alle disposizioni previste dal documento „Perfectae Caritatis”, i religiosi della base parteciparono, ormai, a queste assemblec, nella proporzione, quasi generalmente adottata, di un numero di delegati eletti, pari al numero dei membri di diritto. Tutti questi religiosi erano pieni di buona volontà, ma non erano preparati ad un tale impegno; essi volevano agire, ma non sapevano la via da prendere. Per offrire loro aiuto, molti Istituti organizzarono sessioni preparatorie, consultando esperti, non soltanto su piano dottrinale, spirituale o canonico, ma anche su quello della psicologia e della sociologia, con risultati molto ineguali".

52 Tamże, s. 171: „L'ultimo paragrafo dell'articolo 4 del decreto „Perfectae Caritatis", e in modo perticolare la possibilitá evocata dal motu proprio „Ecclesiae Sanctae" di apportare modifiche alle Costituzioni approvate, furono a volte mal compresi e, soprattutto, male interpretati. Dimendicando che il rinnovamento richiesto dal Concilio doveva prevalentemente appoggiarsi su di una osservanza più consapevole della regola, e che le modifiche autorizzate a titolo di "esperimento" devevano rispettare ,il fine, la natura e il carattere degli istituti" i Capitoli si ritennero obbligati a redigere nuove „Regole di vita". Reagendo alle prescrizioni anteriori, 
O pewnym zamieszaniu podczas dostosowywania konstytucji do zasad Soboru Watykańskiego II, ale również o jednoznacznym stanowisku Kościoła dotyczącym zawartości i roli, jaką mają spełniać konstytucje, może świadczyć dokument Kongregacji Zakonów i Instytutów Świeckich z 2 lutego $1972 \mathrm{r}^{53}$, w którym czytamy: ,,Podjęte eksperymenty w dziedzinie metod rządzenia wywołały niemałe problemy i wątpliwości, zwłaszcza odnośnie do osobistego autorytetu Przełoźonych... Po uprzednim przestudiowaniu sprawy przez konsultorów Ojcowie tej Świętej Kongregacji na plenarnym zebraniu $w$ dniach 24 i 25 września 1971 roku rozważyli następujące wątpliwości:

„1. Czy można, wbrew kanonowi 516, przyjąć rządy kolegialne jako zwyczajną i wyłączną formę rządzenia bądź w całym Instytucie zakonnym, bądź w prowincji, bądź też w poszczególnych domach tak, aby Przełożony, o ile takowy jest, był jedynic tylko wykonawcą decyzji kolegialnych?... Rozważywszy wszystko należycie, Ojcowie na wspomnianym zebraniu jednomyślnie zadecydowali, co następuje:

Ad 1. Negatywnie. W myśl Soboru Powszechnego Watykańskiego II (DZ 14) i adhortacji papieskiej Evangelica testificatio $\mathrm{nr} 25$ (AAS 63/1971/510) Przełożeni powinni posiadać osobistą władzę i uwzględniać $z$ prawa płynący obowiązek zasięgania rady, biorąc pod uwagę granice uprawnień, ogólnie określone czy to przez prawo powszechne, czy partykularne" 54 .

Należy zaznaczyć, że skrzętne usuwanie z konstytucji wszystkiego, co pochodziło od Założycieli oraz pierwszych członków instytutu - a więc również celu i zadań - powodowało smutne następstwa. Niektórzy członkowie, rozgoryczeni taką sytuacją, powtarzali, że nie na takie konstytucje ślubowali, nie do takiego wstępowali instytutu i że obecnie istniejący zakon, zgromadzenie czy instytut świecki nie mają nic wspólnego $z$ pierwotną instytucją $^{55}$.

Kodeks Prawa Kanonicznego z 1983 r. przejął w odniesieniu do instytutów życia konsekrowanego wytyczne Soboru Watykańskiego II oraz innych dokumentów posoborowych. Konstytucje pełnią według Kodeksu rolę nadrzędną i są określane jako kodeks fundamentalny, którego zadaniem jest ochrona i strzeżenie powolania oraz identyczności, czyli tożsamości instytutów, tj. celu i zadań ${ }^{56}$. Dlatego też powinny uwzględniać wszystkie

fortemente minuziose, alle quali per lungo tempo, erano stati sottomessi, i Capitolanti vollero preparare delle Costitutioni puramente spirituali, talvolta anche poetiche, eliminando con cura tutte le norme concrete, fossero pure quelle inerenti alla vita spirituale, comunitaria, apostolica, alla formazione e persino al governo".

${ }^{53}$ Kongregacje Zakonów i Instytutów Świeckich, Dekret Experimenta circa regiminis rationem, 2 lutego 1972 r., Charyzmat życia zakonnego, s. 324-325.

54 Tamże.

55 A. Sauvage, s. 171.

56 Kan. $578 \mathrm{KPK} / 1983$; „Wszyscy powinni wiernie zachowywać myśl i zamierzenia zalożycieli, zatwierdzone przez kompetentną wladzę kościelną, dotyczące natury, celu, ducha i charakteru instytutu, jak również zdrowych jego tradycji, co stanowi dziedzictwo tegoż instytutu"; Kan. $587 \S 1-2$ : „Dla lepszej ochrony własnego powołania oraz identyczności poszczególnych instytutów, kodeks fundamentalny, 
elementy wyliczone w kan. 578 i $587 \S 1$ oraz w innych kanonach Kodeksu. Są to: natura instytutu, jego cel, charakter, dyscyplina czionków, przyjmowanie do instytutu, zasady odnoszące się do formacji oraz przedmiot ślubów lub innych zobowiązań ${ }^{57}$. Należy zauważyć, że chociaż Kodeks Prawa Kanonicznego wymienia tylko te elementy, których nie może zabraknąć $w$ konstytucjach, to jednak każdy z nich - rozpatrywany oddzielnie - zawiera bogatą treść, a wszystkie razem stanowią zasadnicze czynniki życia i sposobu realizacji rad ewangelicznych w instytutach życia konsekrowanego oraz przyczyniają się do zachowania celu i zadań każdej rodziny zakonnej czy instytutu świeckiego ${ }^{58}$.

Konstytucje, na co trzeba zwrócić szczególną uwagę, nie tylko chronią cel, zadania etc. instytutu życia konsekrowanego, ale - jeśli są wiernie zachowywane - stanowią bezpieczną i wypróbowaną drogę do wlasnego uświęcenia. Z tej racji Kodeks Prawa Kanonicznego z 1983 r., mówiąc o obowiązkach członków instytutów zakonnych (a to samo można odnieść do instytutów świeckich i stowarzyszeń życia apostolskiego) przypomina, że „za najwyższą zasadę swego życia zakonnicy winni uznać naśladowanie Chrystusa ukazane w Ewangelii i wyrażone w konstytucjach własnego instytutu"59.

Stolica Apostolska - zgodnie z od dawna stosowaną przez siebie praktyką - chcąc zapobiec dowolnemu interpretowaniu konstytucji oraz wprowadzaniu do nich częstych, mało przemyślanych i przeciwnych nauce Kościoła zmian, w tym też dotyczących celu i zadań - wymaga zatwierdzenia kodeksów fundamentalnych przez kompetentną władzę kościelną i przypomina, że ,tylko za jej zgodą (kodeks ten - J.K.) może być zmieniony" 60 .

\section{Zakończenie}

$Z$ rozważań przedstawionych $w$ artykule wynika, że konstytucje są tak ważne, iż bez nich nie może istnieć żaden instytut życia konsekrowanego. Wyznaczają one nie tylko cel i zadania oraz właściwy sposób postępowania, ale także gwarantują autentyczność wybranej drogi życia.

Pan Bóg, według wypowiedzi papieży ${ }^{61}$, w specjalny sposób przyczynia się do powstania nowego instytutu, obdarzając Założycieli i Zalożycielki laskami koniecznymi do pokonania różnorakich trudności występujących

czyli konstytucje każdego instytutu, oprócz tego, co nakazuje zachować kan. 578, powinny zawierać także normy fundamentalne odnośnie do zarzadzania instytutem i dyscypliny członków, włączenia członków oraz ich formacji, jak również przedmiotu podejmowanych świętych zobowiązań.

Kodeks ten jest zatwierdzany przez kompetentną władzę kościelną i tylko za jej zgodą może być zmieniony".

57 J. Ka lowski, Konstytucje $i$ inne zbiory prawne instytutów życia konsekrowanego wedlug Kodeksu Prawa Kanonicznego z 1983 r., s. 154.

58 Tamże.

59 Kan. 662 KPK/1983.

${ }^{60}$ Kan. 587 \& $1 \mathrm{KPK} / 1983$.

61 Przypis 38. 
podczas organizowania nowego instytutu. Pozostawali oni w glębokiej łączności z Bogiem pisząc konstytucje, na których swoją pieczęć położyła władza Kościoła katolickiego.

Niektórzy teologowie twierdzą ${ }^{62}-$ co w obecnych warunkach może się wydać rzeczą dziwną - że zatwierdzając konstytucje Kościół angażuje swój przywilej nieomylności i stąd broni tego, co uprzednio zaaprobowal. Taka postawa Kościoła wynika jednak bardziej $\mathrm{z}$ chęci obrony charyzmatu instytutu, gdyż tylko jego wierne zachowanie przyczynia się do owocnego działania. „Charyzmat bowiem życia zakonnego w rzeczywistości pochodzi nie $z$ krwi ani z żądzy ciała (por. J 1, 13), ani z postawy umysłu, kształtowanej na wzór tego świata (por. $\mathrm{Rz} 12,2$ ), ale jest owocem Ducha Świętego, działającego zawsze w Kościele"63.

\section{Costituzioni come una garanzia del fine e dello scopo proprio negli Istituti di vita consacrata}

In questo articolo l'autore tratta della sollecitudine della Chiesa per mantenere l'identità, cioè il fine ed i compiti delineati dai fondatori e approvati dalla competente autorità, in tutte le forme della vita consacrata.

Alla base dei documenti promulgati dalla Chiesa è stato dimostrato che, cominciando dal momento delle organizzate forme della realizzazione dei consigli evangelici, la suprema autorità ecclesiale vegliava - per mezzo della legge fondamentale cioè le costituzioni - affinchè gli istituti di vita consacrata fossero fedeli ai loro carismi.

62 R. Bernini, s. 260.

${ }^{63} \mathrm{~Pa}$ a el VI, Evangelica testificatio" n. 11. 